\title{
Wpływ przedsiębiorczości mieszkańców i władz samorządowych na podniesienie atrakcyjności turystycznej regionu na przykładzie gminy Susiec (Roztocze Środkowe)
}

\section{The Influence of Entrepreneurship of Residents and Local Government Authorities on Increasing Tourist Attractiveness of the Region Based on the Example of Susiec Commune (Central Roztocze)}

Streszczenie: Gmina Susiec zaliczana jest do najbardziej atrakcyjnych pod względem walorów turystycznych obszarów w województwie lubelskim. W VI edycji konkursu „7 nowych cudów Polski” organizowanego w 2016 r. przez redakcję „National Geographic Traveler” położony na terenie gminy Susiec rezerwat przyrody „Nad Tanwią” - popularnie nazywany roztoczańskimi szumami - zdobył w głosowaniu VI miejsce. Fakt ten jest m.in. rezultatem rosnącej popularności turystyki na Roztoczu, a także pokłosiem działań podejmowanych w ostatnich latach przez mieszkańców i władze samorządowe gmin Roztocza Środkowego - działań mających na celu stałe podnoszenie atrakcyjności turystycznej regionu i rozwój różnych rodzajów turystyki. Celem badań, zasygnalizowanym w tytule opracowania, była analiza i ocena przemian w sektorze usług turystycznych, jakie zaszły na omawianym obszarze w latach 2000-2016, a także analiza działań przedsiębiorczych podejmowanych zarówno przez władze samorządowe, lokalne organizacje i stowarzyszenia turystyczne, jak i mieszkańców gminy Susiec w celu rozwoju turystyki. W pracy dokonano oceny atrakcyjności turystycznej gminy Susiec według metod przyjętych w literaturze przedmiotu. Zaprezentowano również wyniki badań ankietowych przeprowadzonych wśród turystów odpoczywających w gminie Susiec w okresie wakacji 2016 r. Celem tych badań była m.in. ocena wpływu postaw przedsiębiorczych mieszkańców i władz samorządowych na rozwój turystyki i podniesienie atrakcyjności turystycznej gminy Susiec. Prezentowane opracowanie jest rezultatem badań terenowych prowadzonych na terenie gminy Susiec w latach 2008-2016, a także badań ankietowych, które przeprowadzano w Suścu od lipca do września 2016 r. W przedstawieniu wyników badań posłużono się przede wszystkim metodą opisowo-analityczną, dynamiczno-porównawczą, kartograficznymi metodami prezentacji (kartodiagramem) oraz metodami statystycznymi.

Abstract: Susiec commune belongs to the most attractive regions in the Lubelskie province taking into
account its tourist values. In the 6th edition of the contest " 7 New Wonders of Poland" organised in 2016
by editors of "National Geographic Traveler", the nature reserve "Nad Tanwią" - commonly known
as Roztocze rustles - located within the area of the commune of Susiec got the sixth place in the voting. 
This fact is a result of, among others, the growing popularity of tourism in the Roztocze and the aftermath of the activities undertaken during the recent years by the inhabitants and local government authorities of the communes of the Central Roztocze - the actions aimed at constantly raising the tourist attractiveness of the region and development of various forms of tourism. The objective of the research referred to in the title of the study was to get to know the transformations in the tourism sector services that took place within the examined area in the period from 2000 to 2016 and an analysis of the entrepreneurial activities undertaken by both local government authorities and tourist associations, as well as the inhabitants of the commune of Susiec for the purposes of development of tourism. Assessment of the tourist attractiveness of the Susiec commune according to the methods applied in the subject literature has been conducted in the study. Results of the surveys carried out among tourists relaxing in the commune of Susiec during summer holidays in 2016 have also been presented. The goal of this research was, among others, to assess the influence of the entrepreneurial attitudes of the inhabitants and local government authorities on development of tourism and raising the tourist attractiveness of the Susiec commune. The presented study constitutes a result of the inhouse and field works that have been carried out regularly within the area of the commune of Susiec since 2008. To present the results mainly the following methods have been applied: a descriptive and analytical method, a dynamic comparative method and statistical methods.

Słowa kluczowe: gmina Susiec; przedsiębiorczość; Roztocze; turystyka; zagospodarowanie turystyczne

Keywords: entrepreneurship; Roztocze; Susiec commune; tourism; tourism management

Otrzymano: 11 grudnia 2016

Received: 11 December 2016

Zaakceptowano: 7 marca 2017

Accepted: 7 March 2017

\section{Sugerowana cytacja/Suggested citation:}

Mróz, F., Ziółkowska-Weiss, K. (2017). Wpływ przedsiębiorczości mieszkańców i władz samorządowych na podniesienie atrakcyjności turystycznej regionu na przykładzie gminy Susiec (Roztocze Środkowe). Przedsiębiorczość - Edukacja [Entrepreneurship - Education], 13, 159-179. DOI: $10.24917 / 20833296.13 .12$

\section{Wstęp}

Położona na terenie Roztocza Środkowego gmina Susiec zaliczana jest do najbardziej atrakcyjnych turystycznie obszarów w województwie lubelskim. Po analizie krajowych destynacji turystycznych z ostatnich lat, widać wyraźny trend rosnącej popularności podróży i wypoczynku na terenie Roztocza. Region ten w folderach informacyjnych promuje się jako „niezwykła kraina, pełna nieskażonej przyrody i słońca, najbardziej słoneczna kraina Polski, gdzie lato trwa nieprzerwanie ponad 100 dni. Roztocze to uzdrowisko, które leczy ciało i duszę, mineralne wody i leśne pełne zdrowia powietrze pomogą każdemu odzyskać siły i nabrać radości życia” (Informator turystyczny, 2011). W VI edycji konkursu „7 nowych cudów Polski” organizowanego w 2016 r. przez redakcję „National Geographic Traveler” położony na terenie gminy Susiec rezerwat przyrody „Nad Tanwią" - popularnie nazywany roztoczańskimi szumami - zdobył w głosowaniu VI miejsce z 7,08\% oddanych głosów. W 2008 r. rezerwat ten zdobył także prestiżowy tytuł „Cudu przyrody polskiej” w plebiscycie organizowanym przez ogólnopolski dziennik „Rzeczpospolita”. Fakty te są bezsprzecznie rezultatem rosnącej popularności turystyki 
na Roztoczu, ale także pokłosiem działań podejmowanych w ostatnich latach przez mieszkańców i władze samorządowe gmin Roztocza Środkowego - działań mających na celu stałe podnoszenie atrakcyjności turystycznej regionu i rozwój różnych rodzajów turystyki.

Celem badań, zasygnalizowanym w tytule opracowania, była analiza i ocena przemian w sektorze usług turystycznych, jakie zaszły na badanym obszarze w latach 2000-2016, a także analiza działań przedsiębiorczych podejmowanych zarówno przez władze samorządowe, lokalne organizacje i stowarzyszenia turystyczne, jak i mieszkańców gminy Susiec w celu rozwoju turystyki.

W pracy dokonano oceny atrakcyjności turystycznej gminy Susiec według metod przyjętych w literaturze przedmiotu. Zaprezentowano również wyniki badań ankietowych przeprowadzonych wśród turystów odpoczywających w gminie Susiec w okresie wakacji 2016 r. Celem tych badań była m.in. ocena wpływu postaw przedsiębiorczych mieszkańców i władz samorządowych na rozwój turystyki i podniesienie atrakcyjności turystycznej gminy Susiec.

Prezentowane opracowanie jest rezultatem badań terenowych prowadzonych na terenie gminy Susiec w latach 2008-2016, a także badań ankietowych, które przeprowadzano w Suścu od lipca do września 2016 r. W przedstawieniu wyników badań posłużono się przede wszystkim metodą opisowo-analityczną, dynamiczno-porównawczą, kartograficznymi metodami prezentacji (kartodiagramem) oraz metodami statystycznymi.

\section{Atrakcyjność turystyczna gminy Susiec}

Gmina Susiec jest gminą wiejską położoną w województwie lubelskim, w powiecie tomaszowskim, na pograniczu trzech regionów fizycznogeograficznych: Roztocza Środkowego, Równiny Biłgorajskiej i Płaskowyżu Tarnogrodzkiego. Powierzchnia gminy wynosi 190,52 $\mathrm{km}^{2}$, a 31 grudnia $2016 \mathrm{r}$. na terenie gminy zameldowanych było 7869 osób (Statystyczne vademecum... , 2016; Ewidencja ludności gminy Susiec na dzień 31.12.2016 r.). Obszar gminy Susiec należy do terenów najchętniej odwiedzanych przez turystów w województwie lubelskim. O ich dużej atrakcyjności turystycznej decydują przede wszystkim walory przyrodnicze (lasy, liczne progi skalne tworzące wodospady, wąwozy o stromych zboczach, wydmy i torfowiska), rozwinięta baza noclegowa, bardzo dobrze rozbudowana sieć szlaków turystycznych i ścieżek rowerowych oraz dobra dostępność komunikacyjna. Obszar Roztocza Środkowego, w tym gmina Susiec, charakteryzuje się największym w Polsce wskaźnikiem dni ze słońcem. Z kolei w okresie zimy zalegająca długo pokrywa śnieżna stwarza bardzo dobre warunki do narciarstwa biegowego i organizacji kuligów.

Gmina Susiec położna jest na skraju Parku Krajobrazowego Puszczy Solskiej oraz Krasnobrodzkiego Parku Krajobrazowego. Na obszarze gminy znajdują się trzy rezerwaty przyrody: „Nad Tanwią” (rezerwat krajobrazowy, którego główną atrakcją są wspomniane szumy (szypoty) - 24 urocze progi skalne na Tanwi powstałe w wyniku ruchów tektonicznych), „Czartowe Pole” (rezerwat leśny słynący również z progów skalnych na rzece Sopot i ruin papierni Zamojskich) oraz rezerwat torfowiskowy "Nowiny” o powierzchni 3,8 ha, chroniący torfowiskowe śródleśne bagna i roślinność wodną (Ochrona środowiska i leśnictwo w województwie lubelskim w latach 2008-2012, 2013). Turyści odwiedzający gminę mogą również zobaczyć pomnik przyrody - wodospad na rzece Jeleń - najwyższy $(1,5$ m wysokości) wodospad na Roztoczu Środkowym, malowniczy staw młyński nazywany 
„Morskim Okiem”, kamieniołom w Nowinach oraz wzgórze „Kościółek” w widłach rzeki Tanew i Jeleń, gdzie do XVIII w. znajdowała się cerkiew greckokatolicka i klasztor bazylianów. Ekoturystów i turystów ukierunkowanych na walory przyrodnicze interesują także ekosystemy czterech rzek przepływających przez teren gminy: Tanwi, Jelenia, Sopotu i Potoku Łosinieckiego. Wśród walorów kulturowych gminy Susiec na uwagę zasługują kościół pw. św. Jana Nepomucena w Suścu wzniesiony w latach 1862-1868, kościół pw. opieki św. Józefa i św. Michała Archanioła w Łosińcu (dawna cerkiew), a także miejsce pamięci narodowej - cmentarz wojenny i teren byłego obozu NKWD w Błudku (Pawłowski, 2011). Do nowych walorów kulturowych gminy należy zaliczyć otwarte w 2016 r. Muzeum Pożarnictwa w Oseredku (www.muzeum.susiec.pl). Na uwagę zasługuje również bogaty - a co istotne dla turystów - stale rozbudowywany kalendarz imprez turystycznych, sportowych, kulturowych, historycznych i edukacyjnych. Do imprez cieszących się największą frekwencją wśród turystów i lokalnych mieszkańców należą przede wszystkim: Jarmark Susiecki, w ramach którego organizowane są Sportowa Majówka i Bieg Nad Tanwią (maj), Otwarcie Letniska w Majdanie Sopockim (początek lipca), Transgraniczny Festiwal Pieśni o Roztoczu (ostatni weekend lipca), Dożynki Gminno-Parafialne (koniec sierpnia), Święto Pieczonego Ziemniaka (wrzesień), Rocznica Bitwy pod Łosińcem (wrzesień) oraz Integracyjny Festiwal Piosenki Ludowej na Roztoczu (wrzesień).

Warto również wspomnieć, że w Suścu urodził się Sylwester Chęciński - scenarzysta i reżyser wielu filmów, z których największą oglądalność zyskała komediowa trylogia: Sami swoi, Nie ma mocnych i Kochaj albo rzuć. W 2009 r. w Suścu odsłonięto drewniane figury przedstawiające Pawlaka i Kargula - głównych bohaterów komedii Sylwestra Chęcińskiego.

Dostępność komunikacyjna w turystyce najczęściej charakteryzowana jest w aspekcie dostępności zewnętrznej (spoza regionu do miejsca docelowego) i wewnętrznej (poruszaniu się po miejscu docelowym). Dostępność komunikacyjną zewnętrzną gminy Susiec należy ocenić dobrze. Przez teren gminy przebiega droga powiatowa nr 2546L pomiędzy Józefowem a Tomaszowem Lubelskim oraz drogi powiatowe w kierunku Cieszanowa i Narola. Susiec jest położony w odległości $15 \mathrm{~km}$ od drogi krajowej nr 17, prowadzącej z Warszawy do drogowego przejścia granicznego Polski z Ukrainą w Hrebennem (tzw. Szosy Lubelskiej), a także $65 \mathrm{~km}$ od autostrady A4 (Jarosław - węzeł Wierzbna) i 125 km od Portu Lotniczego „Rzeszów-Jasionka” i 120 km od Portu Lotniczego Lublin SA w Świdniku. Warto również zaznaczyć atrakcyjne położenie gminy względem obiektów wpisanych na Listę światowego dziedzictwa UNESCO - tj. Starego Miasta $\mathrm{z}$ niepowtarzalną, renesansową architekturą w Zamościu $(50 \mathrm{~km})$, Starego Miasta z Wysokim Zamkiem i archikatedralnym soborem św. Jura we Lwowie $(110 \mathrm{~km})$ oraz drewnianych cerkwi w Radrużu (45 km) i w Chotyńcu (55 km). Na terenie gminy Susiec znajduje się stacja obsługiwana przez Przewozy Regionalne. Niestety, pociągi Regio, kursujące na trasie Lublin - Zamość - Susiec - Bełżec - Jarosław (i z powrotem), zatrzymują się w Suścu tylko w okresie weekendu majowego oraz w wakacje. Dostępność turystyczna wewnętrzna gminy Susiec jest bardzo dobra, a to za sprawą gęstej sieci szlaków turystycznych i ścieżek rowerowych.

Baza turystyczna gminy Susiec jest również bardzo dobrze rozwinięta. Na terenie gminy w 2010 r. zarejestrowano 724 miejsca noclegowe (Turystyka $w$ województwie lubelskim, 2010). Należy jednak zwrócić uwagę na stale rosnącą bazę noclegową funkcjonującą 
w ramach Roztoczańskiego Stowarzyszenie Agroturystyczne w Suścu. W 2002 r. Roztoczańskie Stowarzyszenie Agroturystyczne oferowało ponad 1000 miejsc noclegowych w 42 obiektach (dane uzyskane od Krzysztofa Łagowskiego - prezesa Zarządu Roztoczańskiego Stowarzyszenie Agroturystyczne w Suścu). Obok obiektów zrzeszonych w stowarzyszeniu na terenie gminy Susiec funkcjonują jeszcze obiekty noclegowe niezrzeszone dlatego łączną liczbę miejsc noclegowych można ocenić na znacznie większą. Według szacunków prezesa Zarządu Roztoczańskiego Stowarzyszenie Agroturystyczne w Suścu, Krzysztofa Łagowskiego, baza noclegowa gminy to 1300 łóżek. Warto również podkreślić, że w ostatnich latach na terenie gminy widoczne są inwestycje w bazę turystyczną przez indywidulane osoby pracujące za granicą.

Przez gminę Susiec prowadzą najpopularniejsze na Roztoczu rowerowe szlaki turystyczne o randze krajowej i regionalnej. Na szczególną uwagę zasługuje Wschodni Szlak Rowerowy „Green Velo”, który jest obecnie najdłuższą rowerową trasą w Polsce (ponad 2000 km), a także Centralny Szlak Rowerowy Roztocza i Roztoczański Szlak Rowerowy (Susiec - Krasnobród - Zwierzyniec). Popularne wśród rowerzystów odpoczywających na Roztoczu są również szlaki rowerowe lokalne, utworzone w ostatnich latach w gminie Susiec: Rybnica - Maziły, Szlak Łosiów (Susiec - Tomaszów Lubelski) oraz Susiec - Borowe Młyny (tab. 1). W Suścu w sezonie turystycznym funkcjonują wypożyczalnie rowerów m.in. w Ośrodku Wypoczynkowym „Roztoczanka” i w Pensjonacie Szkoleniowo-Wypoczynkowym „Sosnowe Zacisze”. Warto podkreślić, że w gminie rejestruje się najdłuższą sieć ścieżek rowerowych wśród wszystkich gmin Roztocza Środkowego - w 2015 r. było $20,3 \mathrm{~km}$ tras rowerowych (ryc. 1). Rozwinięta sieć szlaków pieszych doskonale nadaje się do coraz to popularniejszych w Polsce wędrówek nordic walking. W sezonie turystycznym kajakarzy i miłośników turystyki kajakowej przyciągają spływy po rzece Tanew, na bardzo malowniczym odcinku Pary - Rebizanty. Z kolei w zimie na terenach leśnych wytyczane są tory narciarskie do biegów w stylu klasycznym. Bardzo wysoko należy także ocenić bazę informacyjną gminy - dotyczy to zarówno dobrze opracowanych tablic informacyjnych, jak i punktu informacji turystycznej funkcjonującego w Gminnym Ośrodku Kultury w Suścu.

Do najczęściej stosowanych $\mathrm{w}$ literaturze przedmiotu metod $\mathrm{w}$ ocenie środowiska geograficznego dla potrzeb turystyki jest metoda bonitacji punktowej. Pomimo że w metodzie tej tkwi także subiektywizm, wynikający zarówno z doboru subiektywnych cech składowych i skal wartości, jak i z wiedzy i indywidualnych upodobań turysty, pozwala ona na uzyskanie obiektywnego wyniku syntetycznego i wydzielenie obszarów o największej atrakcyjności turystycznej badanego regionu (Cabaj, Kruczek, 2007). W prezentowanym opracowaniu do oceny atrakcyjności środowiska przyrodniczego i antropogenicznego gminy Susiec dla potrzeb turystyki wykorzystano metodę bonitacji punktowej opracowaną przez J. Warszyńską (1971), w której autorka przyjęła punktację wybranych cech środowiska (tab. 1) (Cabaj, Kruczek, 2007).

Współczynnik atrakcyjności turystycznej ${ }^{1}$ gminy Susiec wynosi 0,54, co oznacza, że jest to - wg metody J. Warszyńskiej - obszar o dużej atrakcyjności turystycznej.

\footnotetext{
${ }^{1}$ Współczynnik atrakcyjności turystycznej oblicza się, sumując punkty przyznane za występowanie wybranych cech środowiska geograficznego (elementów środowiska w ujęciu krajobrazowo-rekreacyjnym, elementów specjalistycznych, elementów krajoznawczych i punktów dodatkowych) i dzieląc je przez maksymalną, teoretycznie możliwą do przydzielenia sumę punktów. Wartość współczynnika atrakcyjności waha się od 0 do 1, przy czym wartość 1 oznacza maksymalny teoretyczny stopień atrakcyjności, 0 - zupełny brak
} 
Ryc. 1. Długość ścieżek turystycznych w wybranych gminach Roztocza Środkowego w 2014 r.

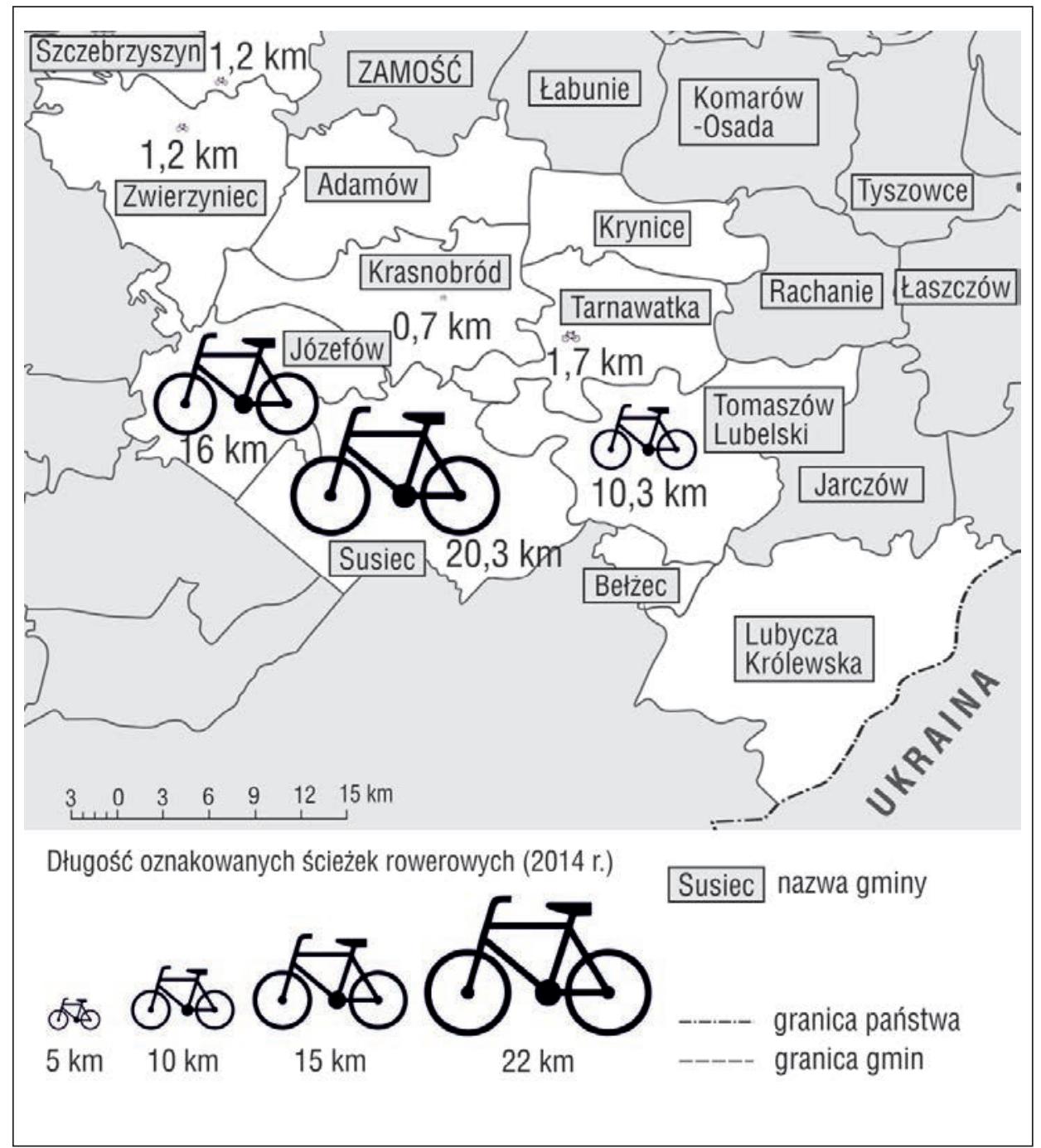

Źródło: opracowanie własne na podstawie: Statystyczne vademecum samorządowca 2015 (2016)

Uwzględniając w ocenie dostępność komunikacyjną i zagospodarowanie turystyczne, gmina Susiec jest obszarem o dużych walorach turystycznych, dostępnym komunikacyjnie z zagospodarowaniem turystycznym częściowym (Warszyńska, 1971).

atrakcyjności. Wartościom współczynnika przypisano oceny słowne: ponad 0,7 - miejscowość/gmina szczególnie atrakcyjna turystycznie; 0,4-0,7 - miejscowość/gmina o dużej atrakcyjności turystycznej; 0,2-0,4 miejscowość/gmina o średniej atrakcyjności turystycznej; poniżej 0,2 - miejscowość/gmina o małej atrakcyjności turystycznej. Patrz: Warszyńska (1971: 107-108); Cabaj, Kruczek (2007: 28). 
Tab. 1. Wybrane szlaki turystyczne i ścieżki rowerowe w gminie Susiec

\begin{tabular}{|c|c|c|c|}
\hline Nazwa szlaku & Przebieg szlaku/kolor znakowania & $\begin{array}{c}\text { Długośćć } \\
\text { szlaku }[\mathrm{km}]\end{array}$ & $\begin{array}{l}\text { Długość } \\
\text { szlaku na } \\
\text { terenie } \\
\text { gminy } \\
\text { Susiec }[\mathrm{km}] \\
\end{array}$ \\
\hline $\begin{array}{l}\text { Szlak Szumów } \\
\text { (pieszy) }\end{array}$ & $\begin{array}{l}\text { Susiec PKP - wodospad na rzece Jeleń - } \\
\text { Zamczysko - rezerwat przyrody „Nad } \\
\text { Tanwią” - Rebizanty - Sikliwce - Susiec } \\
\text { PKP (znaki niebieskie) }\end{array}$ & 16,9 & 16,9 \\
\hline $\begin{array}{l}\text { Szlak Południowy } \\
\text { (pieszy) }\end{array}$ & $\begin{array}{l}\text { Susiec PKP - wodospad na rzece Jeleń - } \\
\text { rezerwat przyrody „Nad Tanwią” - } \\
\text { Rebizanty - Korkosze - Huta Szumy - } \\
\text { Narol (znaki żółte) } \\
\end{array}$ & 17,0 & 10,0 \\
\hline $\begin{array}{l}\text { Szlak Walk } \\
\text { Partyzanckich } \\
\text { (pieszy) }\end{array}$ & $\begin{array}{l}\text { Tomaszów Lubelski - Pasieki - Łosiniec } \\
\text { (cmentarz wojenny) - Wólka Łosiniecka - } \\
\text { Susiec - wzgórze Kościółek (Zamczysko) - } \\
\text { Borowe Młyny - Osuchy - Sigła - Górecko } \\
\text { Kościelne - Margole - Aleksandrów - } \\
\text { Majdan Nowy - Zanie - Budziarze - } \\
\text { Bidaczów Stary (znaki czarne) }\end{array}$ & 143,0 & 22,0 \\
\hline $\begin{array}{l}\text { Szlak im. Władysławy } \\
\text { Podobińskiej (pieszy) }\end{array}$ & $\begin{array}{l}\text { Susiec PKP - Łasochy - wzniesienie } \\
\text { Wapielnia - Szur - Krasnobród - } \\
\text { Suchowola - Lipsko - Zamość PKP (znaki } \\
\text { zielone) }\end{array}$ & 56,5 & 7,5 \\
\hline $\begin{array}{l}\text { Szlak Krawędziowy } \\
\text { (pieszy) }\end{array}$ & $\begin{array}{l}\text { Susiec - Oseredek - Błudek - Nowiny - } \\
\text { rezerwat „Czartowe Pole” - Pardysówka - } \\
\text { Józefów -Górecko Kościelne - Rezerwat } \\
\text { „Szum” - Górecko Stare - Florianka - } \\
\text { Sochy - Zwierzyniec (znaki czerwone) }\end{array}$ & 54,0 & 17,0 \\
\hline $\begin{array}{l}\text { Szlak Rowerowy } \\
\text { Polski Wschodniej } \\
\text { Green Velo }\end{array}$ & $\begin{array}{l}\text { Elblag - Zwierzyniec - Susiec - Narol - } \\
\text { Horyniec Zdrój - Końskie }\end{array}$ & $\begin{array}{r}\text { ponad } \\
2000\end{array}$ & \\
\hline $\begin{array}{l}\text { Centralny Szlak } \\
\text { Rowerowy }\end{array}$ & $\begin{array}{l}\text { Kraśnik - Szczebrzeszyn - Zwierzyniec - } \\
\text { Górecko Kościelne - Józefów - Susiec - } \\
\text { Narol - Hrebenne (znaki czerwone) }\end{array}$ & 179,0 & 21,0 \\
\hline \begin{tabular}{|l|} 
Roztoczański Szlak \\
Rowerowy
\end{tabular} & $\begin{array}{l}\text { Zwierzyniec - Krasnobród - Majdan } \\
\text { Sopocki }\end{array}$ & 38,0 & \\
\hline $\begin{array}{l}\text { Trasa Rowerowa } \\
\text { Ziemi Józefowskiej } \\
\text { |na Roztoczu }\end{array}$ & $\begin{array}{l}\text { Józefów - rezerwat „Czartowe Pole” - } \\
\text { Majdan Sopocki - Górecko Kościelne - } \\
\text { Józefów }\end{array}$ & 74,0 & \\
\hline $\begin{array}{l}\begin{array}{l}\text { Szlak Łosiowy } \\
\text { (rowerowy) }\end{array} \\
\end{array}$ & Susiec - Tomaszów Lubelski & 16,5 & 11,5 \\
\hline \begin{tabular}{|l|} 
Szlak rowerowy \\
do Borowych Młynów
\end{tabular} & Susiec - Borowe Młyny - Susiec & 11,0 & 8,0 \\
\hline \begin{tabular}{|l|} 
Szlak rowerowy \\
Rybnica - Maziły \\
\end{tabular} & Rybnica - Maziły & 5,0 & \\
\hline $\begin{array}{l}\text { Ścieżka spacerowa } \\
\text { w rezerwacie } \\
\text { „Czartowe Pole" }\end{array}$ & Rezerwat przyrody „Czartowe Pole” & 1,3 & 1,3 \\
\hline
\end{tabular}




\begin{tabular}{|l|l|c|c|}
\hline $\begin{array}{l}\text { Ścieżka przyrodniczo- } \\
\text { dydaktyczna } \\
\text { Nadleśnictwa Józefów } \\
\text { „Nad Tanwią” }\end{array}$ & Rezerwat przyrody „Nad Tanwią” & 3,0 & 3,0 \\
\hline Ścieżka spacerowa & Rebizanty - Susiec (znaki zielone) & 2,8 & 2,8 \\
\hline $\begin{array}{l}\text { Ścieżka rowerowa } \\
\text { (wydzielony pas } \\
\text { jezdni) }\end{array}$ & $\begin{array}{l}\text { Tomaszów Lubelski - Susiec - Rebizanty - } \\
\text { Paary }\end{array}$ & 20,0 & 15,0 \\
\hline
\end{tabular}

Źródło: opracowanie własne na podstawie: www.turystyka.susiec.pl/szlaki,piesze.php?readmore=71; Turystyka w województwie lubelskim w 2010 r. (2011); Mapa turystyczna: Susiec. Rowerem po Roztoczu. (2015); Susiec. Rowerem po Roztoczu... (2016)

Tab. 2. Metoda oceny atrakcyjności środowiska geograficznego wg J. Warszyńskiej oraz ocena środowiska geograficznego dla potrzeb turystyki gminy Susiec

\begin{tabular}{|c|c|c|}
\hline Cecha & Liczba punktów & $\begin{array}{c}\text { Liczba punktów } \\
\text { w ocenie środowiska } \\
\text { geograficznego dla } \\
\text { potrzeb turystyki gminy } \\
\text { Susiec } \\
\end{array}$ \\
\hline \multicolumn{3}{|c|}{ Wysokość bezwzględna (maks. 5 pkt) } \\
\hline Ponad 800 m n.p.m. & 5 & - \\
\hline 500-800 m n.p.m. & 3 & - \\
\hline 300-500 m n.p.m. & 1 & 1 \\
\hline Poniżej 300 m n.p.m. & 1 & - \\
\hline \multicolumn{3}{|l|}{ Wysokość względna (maks. 5 pkt) } \\
\hline Ponad $1000 \mathrm{~m}$ & 5 & - \\
\hline $500-1000 \mathrm{~m}$ & 4 & - \\
\hline $300-500 \mathrm{~m}$ & 3 & - \\
\hline $100-300 \mathrm{~m}$ & 2 & 2 \\
\hline $50-100 \mathrm{~m}$ & 1 & - \\
\hline Poniżej $50 \mathrm{~m}$ & 0 & - \\
\hline \multicolumn{3}{|c|}{ Atrakcyjność wód powierzchniowych (maks. 5 pkt) } \\
\hline $\begin{array}{l}\text { Wody stojące o klasie czystości I i II } \\
\text { klasy, temp. ponad } 18^{\circ} \mathrm{C} \text {, z plażami } \\
\text { i możliwością uprawiania sportów } \\
\text { wodnych; także cieki o klasie czystości } \\
\text { I i II, o przepływie ponad } 20 \mathrm{~m}^{3} / \mathrm{s} \text {, } \\
\text { temp. ponad } 18^{\circ} \mathrm{C} \text {, z naturalnymi } \\
\text { kąpieliskami i plażami }\end{array}$ & 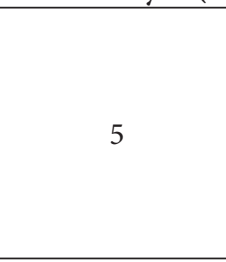 & 5 \\
\hline $\begin{array}{l}\text { Cieki o klasie czystości I i II, } \\
\text { o przepływie } 10-20 \mathrm{~m}^{3} / \mathrm{s} \text {, temp. } \\
\text { ponad } 18^{\circ} \mathrm{C} \text {, z możliwością budowy } \\
\text { naturalnych basenów przepływowych }\end{array}$ & 4 & - \\
\hline $\begin{array}{l}\text { Cieki o klasie czystości I i II, } \\
\text { o przepływie } 5-10 \mathrm{~m}^{3} / \mathrm{s} \text {, temp. } \\
\text { ponad } 18^{\circ} \mathrm{C}, \mathrm{z} \text { możliwością budowy } \\
\text { naturalnych basenów przepływowych }\end{array}$ & 3 & - \\
\hline
\end{tabular}




\begin{tabular}{|c|c|c|}
\hline $\begin{array}{l}\text { Cieki o klasie czystości I i II, przepływ } \\
\text { poniżej } 5 \mathrm{~m}^{3} / \mathrm{s} \text {, temp. poniżej } 18^{\circ} \mathrm{C} \text {, } \\
\text { z naturalnymi kąpieliskami i plażami }\end{array}$ & 2 & - \\
\hline $\begin{array}{l}\text { Cieki o małym znaczeniu dla rekreacji } \\
\text { ze względu na mały przepływ (poniżej } \\
5 \mathrm{~m}^{3} / \mathrm{s} \text { ) i zanieczyszczenie - III klasa } \\
\text { czystości }\end{array}$ & 1 & - \\
\hline \multicolumn{3}{|c|}{ Lesistość (maks. 5 pkt) } \\
\hline Powyżej 50\% powierzchni ogólnej & 5 & 5 \\
\hline 30-50\% powierzchni ogólnej & 4 & - \\
\hline 20-30\% powierzchni ogólnej & 3 & - \\
\hline 10-20\% powierzchni ogólnej & 2 & - \\
\hline 2-10\% powierzchni ogólnej & 1 & - \\
\hline Poniżej 2\% powierzchni ogólnej & 0 & - \\
\hline \multicolumn{3}{|l|}{ Walory specjalistyczne (maks. 21 pkt) } \\
\hline $\begin{array}{l}\text { Warunki do uprawiania sportów } \\
\text { wodnych }\end{array}$ & $1-3$ & 3 \\
\hline Warunki do uprawiania myślistwa & $1-3$ & 1 \\
\hline Warunki do uprawiania wędkarstwa & $1-3$ & 3 \\
\hline Warunki do uprawiania narciarstwa & $1-3$ & 1 \\
\hline $\begin{array}{l}\text { Warunki do uprawiania turystyki } \\
\text { wysokogórskiej }\end{array}$ & $1-3$ & - \\
\hline Warunki do uprawiania taternictwa & $1-3$ & - \\
\hline Istnienie cieplic, wód mineralnych & $1-3$ & - \\
\hline \multicolumn{3}{|c|}{ Walory krajoznawcze (maks. 14 pkt) } \\
\hline $\begin{array}{l}\text { Istnienie obiektów zabytkowych } \\
\text { grupy } 0\end{array}$ & 3 & - \\
\hline $\begin{array}{l}\text { Istnienie obiektów zabytkowych grupy } \\
\text { I i II }\end{array}$ & 2 & - \\
\hline $\begin{array}{l}\text { Istnienie obiektów zabytkowych grupy } \\
\text { III i IV }\end{array}$ & 1 & 1 \\
\hline $\begin{array}{l}\text { Zespoły folklorystyczne o szczególnie } \\
\text { bogatej treści i formie }\end{array}$ & 3 & - \\
\hline $\begin{array}{l}\text { Występowanie pojedynczych } \\
\text { elementów folklorystycznych }\end{array}$ & $1-2$ & 2 \\
\hline $\begin{array}{l}\text { Występowanie obiektów kultu } \\
\text { narodowego w skali regionalnej, } \\
\text { krajowej i międzynarodowej (ze } \\
\text { szczególnym uwzględnieniem miejsc } \\
\text { męczeństwa i walki o wolność narodu) }\end{array}$ & $1-3$ & 2 \\
\hline $\begin{array}{l}\text { Ośrodki o silnej koncentracji obiektów } \\
\text { krajoznawczych o znaczeniu w skali } \\
\text { krajowej i międzynarodowej }\end{array}$ & 3 & - \\
\hline \multicolumn{3}{|c|}{ Punkty dodatkowe (maks. 8 pkt) } \\
\hline Korzystna ekspozycja stoków & 1 & 1 \\
\hline $\begin{array}{l}\text { Szczególne właściwości mezo- } \\
\text { i mikroklimatyczne }\end{array}$ & 1 & 1 \\
\hline
\end{tabular}




\begin{tabular}{|l|c|c|}
\hline $\begin{array}{l}\text { Szczególne wartości wód } \\
\text { w uatrakcyjnieniu krajobrazu }\end{array}$ & 1 & 1 \\
\hline $\begin{array}{l}\text { Zespoły krajobrazowe, w których } \\
\text { wszystkie uwzględnione cechy } \\
\text { środowiska występują w dużym } \\
\text { nasileniu }\end{array}$ & 1 & 1 \\
\hline $\begin{array}{l}\text { Istnienie osobliwości krajobrazowych, } \\
\text { takich jak: turnie, wodospady, doliny } \\
\text { przełomowe, groty itp. }\end{array}$ & 1 & 1 \\
\hline $\begin{array}{l}\text { Występowanie rzadkich gatunków } \\
\text { flory i fauny }\end{array}$ & 1 & 1 \\
\hline $\begin{array}{l}\text { Istnienie parków narodowych oraz } \\
\text { rezerwatów dostępnych dla ruchu } \\
\text { turystycznego }\end{array}$ & 1 & 1 \\
\hline $\begin{array}{l}\text { Równoczesne występowanie } \\
\text { elementów środowiska naturalnego } \\
\text { o wysokich walorach turystycznych } \\
\text { oraz obiektów krajoznawczych }\end{array}$ & 1 & \\
\hline SUMA & 63 & 34 \\
\hline
\end{tabular}

Źródło: Warszyńska (1971: 105-111); por. Cabaj, Kruczek (2007: 27-28); Ochrona środowiska i leśnictwo... (2013)

Przedsiębiorczość władz samorządowych i mieszkańców gminy Roztocze a podniesienie atrakcyjności turystycznej regionu

Przedsiębiorczość jest powszechnie traktowana jako jeden z podstawowych czynników rozwoju społecznego i gospodarczego w układach przestrzennych o różnej skali (krajowych, regionalnych, lokalnych). Szczególnego znaczenia nabiera ona w Polsce i innych krajach europejskich transformujących swoje gospodarki, zwłaszcza w warunkach kryzysu gospodarczego, gdyż odgrywa dużą rolę w utrzymaniu dynamiki i przyspieszeniu wzrostu gospodarczego oraz łagodzeniu skutków bezrobocia strukturalnego (Płaziak, Rachwał, 2015). Jak wskazali Z. Zioło i T. Rachwał (2012), wynika to z faktu coraz większej roli przedsiębiorcy, podejmującego określone decyzje dotyczące lokalizacji i kierunków rozwoju przedsiębiorstwa, które przez swoje relacje w układach przestrzennych wpływają na rozwój bądź recesję tych układów. Procesy przemian społeczno-gospodarczych i kulturowych w różnego typu układach przestrzennych są związane z podejmowaniem określonych decyzji, u podstaw których leży przedsiębiorczość konkretnych osób czy zespołów, w tym przedsiębiorców i przedstawicieli władz samorządowych i centralnych.

Turystyka jest obecnie główną szansą rozwoju społeczno-gospodarczego gminy Susiec. Zarówno władze samorządowe, jak i lokalni przedsiębiorcy oraz mieszkańcy gminy dostrzegają w rozwoju turystyki możliwość wzrostu swojej pozycji konkurencyjnej. Kluczowym w tym zakresie krokiem jest wzrost postaw przedsiębiorczych firm, władz samorządowych oraz mieszkańców gminy, aktywność indywidualna i podnoszenie konkurencyjności oferowanych produktów turystycznych (Zioło, 2016). Działalność przedsiębiorcza skierowana na rozwój turystyki powinna zakładać wprowadzenie innowacji, a więc działań stosujących nowe rozwiązania, zwłaszcza w organizowaniu 
i budowie (rozbudowie) infrastruktury turystycznej, technicznej i usługowej, w tworzeniu i sprzedaży markowych produktów turystycznych, szukaniu nowych odbiorców (turystów), promocji walorów turystycznych Roztocza (w kraju i za granicą), poprawie jakości obsługi ruchu turystycznego (szkolenia personelu obsługi ruchu turystycznego), poprawie dostępności komunikacyjnej oraz wzbogacaniu kalendarza imprez turystycznych.

Biorąc pod uwagę przyjęte $\mathrm{w}$ literaturze przedmiotu rodzaje przedsiębiorczości: przedsiębiorczość gospodarcza, intelektualna, administracyjna - realizowana w sektorze publicznym - i społeczna (Oniszczuk-Jastrzębek, 2011) przyjrzyjmy się postawom przedsiębiorczym w zakresie rozwoju turystyki w gminie Susiec.

Od 2007 r. gmina należy do Lokalnej Organizacji Turystycznej „Roztocze”- stowarzyszenia powstałego w 2007 r., skupiającego samorządy (powiat tomaszowski, gminy: Bełżec, Krynice, Lubycza Królewska, Susiec i Tarnawatka oraz miasto i gmina: Cieszanów, Narol, Tomaszów Lubelski i Tyszowce), przedsiębiorców, organizacje pozarządowe i osoby fizyczne. Głównym celem LOT „Roztocze” jest m.in. „kreowanie wizerunku regionu turystycznego Roztocza poprzez wspieranie działań na rzecz rozwoju turystyki i promocję" (www.roztoczewita.pl). Z gminy Susiec do organizacji należy Roztoczańskie Stowarzyszenie Agroturystyczne w Suścu, a także przedsiębiorcy: Ośrodek Wczasowy „Roztoczanka” w Suścu, Pensjonat Szkoleniowo-Wypoczynkowy „Sosnowe Zacisze”, Agroturystyka „Stokrotka” w Suścu, Agroturystyka „Kędrawka” w Ciotuszy Nowej, Domki „Nad Potokiem” w Rybnicy, „Aga” Pokoje Gościnne w Suścu, Agroturystyka „Wypoczynek u Piotra” w Nowinach oraz Kajaki w Suścu.

Ciekawym pomysłem Lokalnej Organizacji Turystycznej Roztocze są „Dukaty z Roztocza": 7 gryfinów w Tyszowcach, 7 florianów w Narolu, 7 szypotów w Suścu i 7 tomaszów w Tomaszowie Lubelskim.

Według badań ankietowych przeprowadzonych przez Lokalną Organizację Turystyczną i partnerów, Susiec należy do najpopularniejszych baz wypadowych turystów rowerowych - po Zwierzyńcu i Krasnobrodzie (Roztocze w oczach rowerzystów, 2016). W ostatnim dziesięcioleciu na terenie gminy przeprowadzono szereg inwestycji związanych z rozbudową bazy turystycznej dla rowerzystów. Projekty zostały głównie zrealizowane przez władze samorządowe gminy, ale włączyły się w nie również inne podmioty. LOT Roztocze wspólnie z Roztoczańskim Stowarzyszeniem Agroturystycznym w Suścu i Stowarzyszeniem Rowerowe Roztocze promowali 2016 r. jako „Rowerowy Rok Roztocza”, organizując wiele rajdów i imprez rowerowych. 9 lutego 2016 r. z inicjatywy wójta gminy Susiec - Zbigniewa Naklickiego - odbyło się spotkania przedstawicieli władz samorządowych i przedsiębiorców, a jego celem było podsumowanie wydania przewodnika i zestawu dziewięciu map pod tytułem „Rowerem po Roztoczu”. W trakcie zebrania zaproponowano szereg ciekawych i innowacyjnych projektów służących dalszemu rozwojowi turystyki rowerowej na Roztoczu, m.in. powstanie „Roztoczańskiej Wypożyczalni Rowerowej” z możliwością wypożyczenia rowerów i pozostawienia w innym miejscu, z transportem osób, rowerów i bagażu (Rowerowa koalicja na Roztoczu, 2016). Bardzo ważnym wydarzeniem, które w znaczący sposób podniosło atrakcyjność turystyczną regionu, było otwarcie Szlaku Rowerowego Polski Wschodniej Green Velo w 2015 r. 
W ostatnim dziesięcioleciu władze samorządowe gminy Susiec zrealizowały szereg inwestycji związanych z rozbudową infrastruktury turystycznej i rekreacyjnej. Do największych projektów zaliczyć należy budowę i zagospodarowanie terenów wokół zalewu w Majdanie Sopockim. Całkowity koszt inwestycji wyniósł 3411 584, 99 zł, przy wsparciu finansowym tej inwestycji w postaci środków unijnych w kwocie 2236 500, 11 zł². Ważną inwestycją podnoszącą bezpieczeństwo i komfort podróżowania rowerzystów była budowa ścieżki rowerowej prowadzącej z Suśca do parkingu w Rebizantach przy rezerwacie „Nad Tanwią”. W okresach programowania 2004-2006 i 2006-2013 władze samorządowe gminy Susiec zrealizowały ponadto inne projekty związane z turystyką m.in. budowę wieży widokowej w Suścu, oznakowanie i budowę infrastruktury Szlaku Geoturystycznego Roztocza Środkowego. Wartość projektów „turystycznych” wykonanych w tym okresie w gminie Susiec to 6457 049,07 zł (wartość dofinansowania: $4691013,49 \mathrm{zl})$.

W 2015 r. ze środków gminy Susiec wykonano szereg remontów ulic w Suścu, wykonano tablice informacyjno-kierunkowe z Suśca do rezerwatu „Nad Tanwią” oraz do zalewu w Majdanie Sopockim, zbudowano budki strażnicze przy rzece Tanew, zrealizowano prace wykończeniowe przy parkingu w Rebizantach i przy moście na rzece Tanew, przeprowadzono remont pomostów i schodów w rezerwacie „Nad Tanwią”, a także balustrad w kamieniołomach w Nowinach (www.susiec.pl). We wrześniu 2015 r. na stadionie GOSiR w Suścu otwarto „PZU Trasy Zdrowia” z wieloma stacjami do gimnastyki. Projekt został zrealizowany przez gminę Susiec w ramach projektu „PZU Trasy Zdrowia” współfinansowanego przez Fundację PZU Zdrowie (www.turystyka.susiec.pl).

W podniesieniu atrakcyjności turystycznej gminy Susiec zwłaszcza w aspekcie walorów kulturowych bardzo ważnym projektem była budowa budynku Muzeum Pożarnictwa w Oseredku. Muzeum gromadzi obecnie ponad 400 eksponatów. Całkowity koszt budowy obiektu wyniósł 1 030,6 tys. zł. W 2016 r. ze środków gminy Susiec dokonano poprawy bazy informacyjnej. W siedmiu miejscach na terenie gminy postawiono tablice informacyjne o tematyce historycznej i geograficznej.

Bardzo dobrym przykładem postaw przedsiębiorczych lokalnych mieszkańców (przedsiębiorczości gospodarczej i intelektualnej) jest działalność wspomnianego już Roztoczańskiego Stowarzyszenia Agroturystycznego w Suścu. Celem stowarzyszenia są działania na rzecz rozwoju turystyki wiejskiej i agroturystyki na terenie Roztocza, a także ochrona i promocja interesów zrzeszonych członków (www.susiec.com.pl).

Doskonałym materiałem promocyjnym Roztocza jest wydawany od 2012 r. Magazyn Turystyczny „Magiczne Roztocze”. Opracowanie wydaje Biuro Turystyczne QUAND we współpracy z Lokalną Organizacją Turystyczną Roztocze oraz roztoczańskimi samorządami, Roztoczańskim Parkiem Narodowym, nadleśnictwami i wieloma przedsiębiorcami. W magazynie zamieszczane są informacje o walorach turystycznych regionu, mapy, reklamy przedsiębiorców branży turystycznej, opisy szlaków turystycznych, praktyczne informacje dla odwiedzających oraz kalendarium wydarzeń kulturalnych. Warto podkreślić, że magazyn jest dostępny bezpłatnie w obiektach bazy noclegowej i gastronomicznej, punktach informacji turystycznej oraz w wybranych marketach na Roztoczu. W 2016 r. nakład magazynu wyniósł 80 tys. egzemplarzy.

\footnotetext{
${ }^{2}$ Podsumowanie pracy Rady Gminy Susiec (2010-2014). Pozyskano z: www.susiec.pl/images/docs/podsumowanie.pdf.
} 
Przedsiębiorczość władz samorządowych i mieszkańców gminy Roztocze

a podniesienie atrakcyjności turystycznej regionu w ocenie respondentów

\section{Metodyka badań}

W 2016 r. autorzy prezentowanego opracowania przeprowadzili badania ankietowe, których celem była ocena wpływu postaw przedsiębiorczych mieszkańców i władz samorządowych na rozwój turystyki i podniesienie atrakcyjności turystycznej gminy Susiec przez turystów odpoczywających w gminie Susiec. W badaniach wykorzystano kwestionariusz ankiety, który składał się ze wstępu, metryczki oraz 22 pytań zamkniętych - zarówno z odpowiedziami ilościowymi, jak i kategorialnymi (kafeteria dysjunktywna: respondent mógł wskazać jedną z możliwych odpowiedzi i koniunktywna: respondent mógł wskazać więcej niż jedną odpowiedź). Badania pilotażowe zostały przeprowadzone w czerwcu 2016 r., a ich głównym celem była weryfikacja przygotowanej ankiety. Właściwe badania ankietowe przeprowadzano od 1 lipca do 15 września 2016 r. w trzech miejscach w gminie Susiec: w rezerwacie przyrody „Nad Tanwią”, w Ośrodku Wypoczynkowym „Roztoczanka” w Suścu oraz na wieży widokowej w Suścu. Badaniami ankietowymi objęto w sumie 162 turystów wypoczywających na terenie gminy Susiec. Metoda próby badawczej to nielosowy dobór celowy. Zgromadzone podczas badań materiały zostały uporządkowane i poddane procedurze sprawdzenia, w wyniku której wyeliminowano cztery kwestionariusze ze względu na tylko częściowe ich wypełnienie przez respondentów. Zebrane materiały zostały opracowane statystycznie w formie graficznej oraz w formie tablic wynikowych.

\section{Wyniki i analiza badań ankietowych}

Ponad połowę ogółu badanych (55\%) stanowiły kobiety, 45\% stanowili mężczyźni. Najliczniejszą grupę wiekową byli respondenci w wieku 36-45 lat (37\% ogółu) oraz w wieku 25-35 lat (28\% ogółu) (tab. 4). Ponad połowa (51\%) respondentów, oceniając swoją sytuację materialną, określiła, że jest ona dobra, zaś $14 \%$ badanych, że jest ona bardzo dobra. Tylko 2 ankietowanych oceniło swoją sytuacją materialną jako bardzo złą, żadna osoba nie zadeklarowała, że jest zła. Ponad 35\% respondentów zamieszkiwało województwo podkarpackie, a nieco ponad 30\% ogółu - województwo lubelskie. Ankietowani zamieszkiwali również województwa: śląskie (12 osób), mazowieckie (12 osób), małopolskie (10 osób) oraz wielkopolskie i pomorskie (po 2 osoby).

Ponad $1 / 3$ respondentów wskazała, że po raz pierwszy przyjechała do gminy Susiec i na Roztocze w celach turystycznych. Z kolei o tym, że Roztocze jest regionem, który potrafi zauroczyć wielu turystów, świadczyć może, że ponad 13\% (21 osób) badanych przyjeżdża na Roztocze co najmniej raz w roku. Wśród ankietowanych są również osoby, które stanowią $6 \%$ wszystkich ankietowanych (10 osób), odwiedzające Roztocze kilka razy w roku. Odpowiedzi na to pytanie przedstawiono na rycinie 2.

Autorów opracowania interesowało, w jaki sposób ankietowani spędzają swój czas oraz jaki rodzaj turystyki uprawiają, będąc na Roztoczu. Najbardziej preferowanym rodzajem turystyki aktywnej wśród badanej grupy respondentów jest turystyka piesza - którą wskazało 129 respondentów. W pytaniu tym ankietowani mogli udzielić maksymalnie 3 odpowiedzi, wybierając poszczególne aktywności turystyczne, które uprawiają podczas 
Ryc. 2. Rozkład odpowiedzi badanych na pytanie: „Który raz przyjechał(a) Pan(i) na Roztocze w celach turystycznych?"

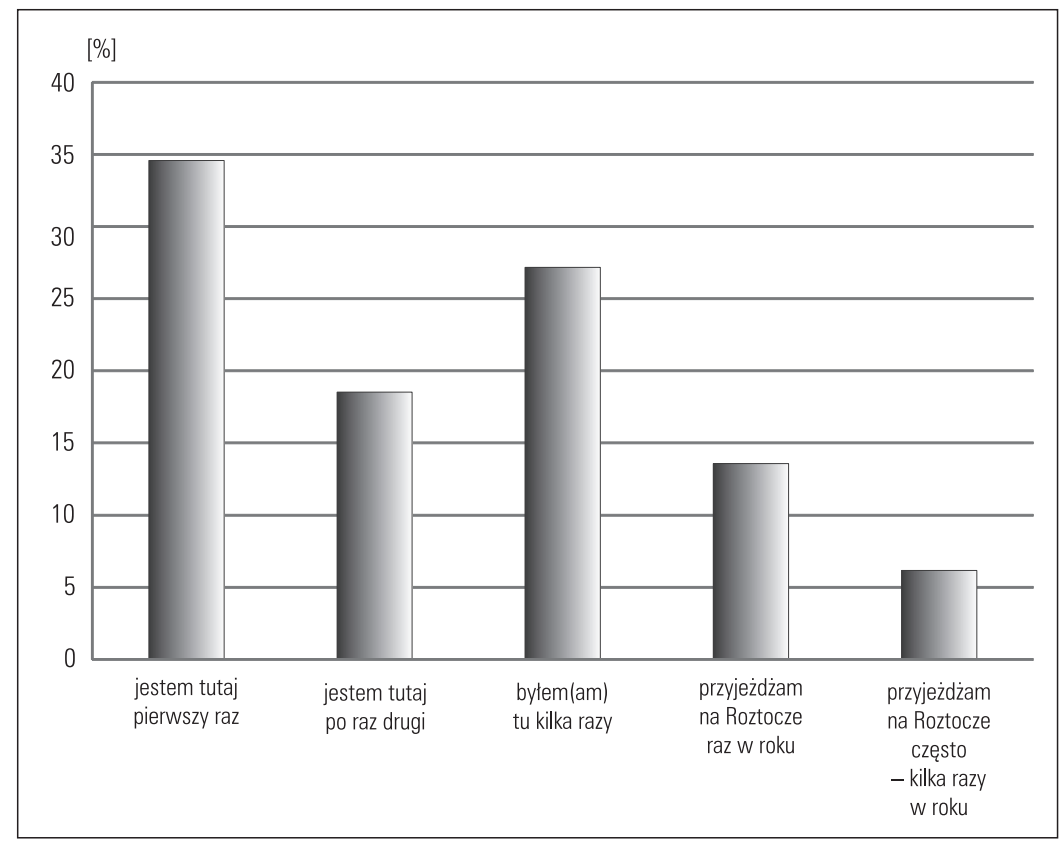

Źródło: opracowanie własne na podstawie przeprowadzonych badań

Ryc. 3. Rozkład odpowiedzi badanych na pytanie: „Jaki rodzaj turystyki aktywnej najczęściej Pan(i) uprawia przebywając na Roztoczu?"

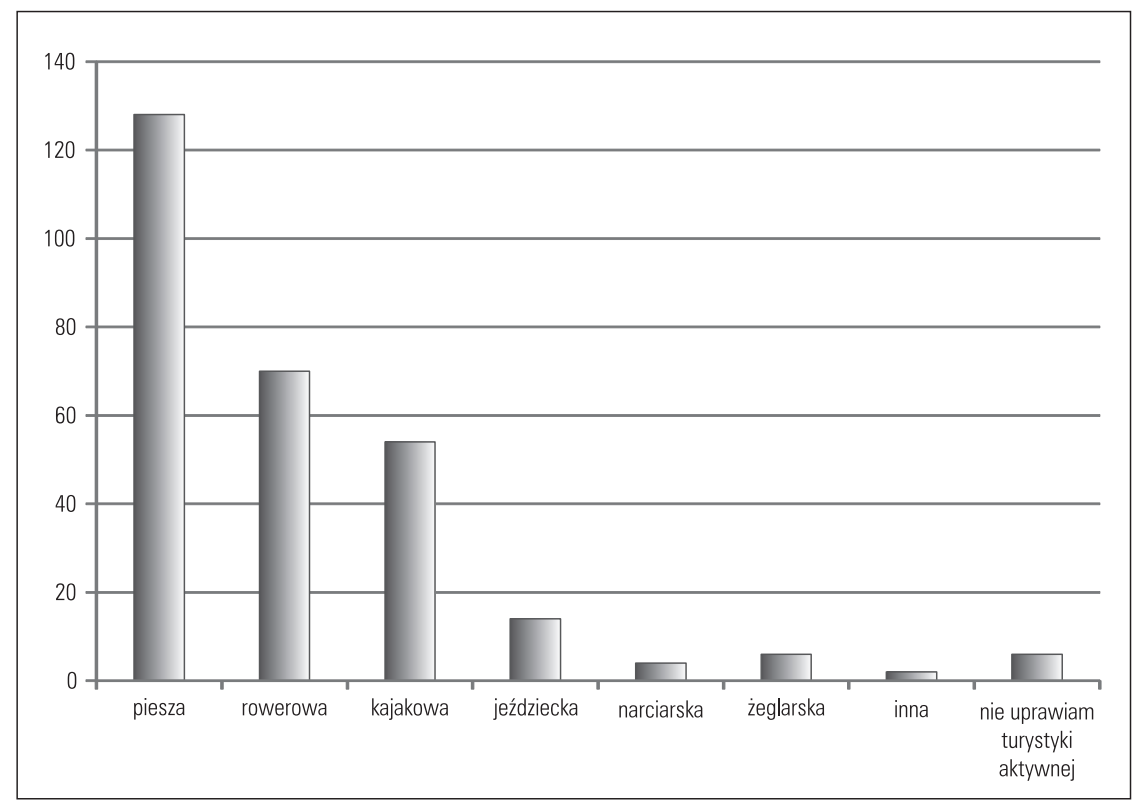

Źródło: opracowanie własne na podstawie przeprowadzonych badań 
przebywania na Roztoczu. Druga pod względem popularności jest turystyka rowerowa (70 udzielonych odpowiedzi), a następnie turystyka kajakowa (53 respondentów) oraz turystyka jeździecka - 12 odpowiedzi. Wyniki poszczególnych rodzajów aktywności turystycznych wybieranych przez respondentów przedstawia rycina 3.

Kolejne pytanie zadane w kwestionariuszu ankietowym przez autorów tekstu dotyczyło oceny atrakcyjności turystycznej gminy Susiec (ryc. 4). Ankietowani mieli do wyboru skalę od 1 do 6, w której oceniali walory turystyczne, przyporządkowując odpowiednią skalę, gdzie 1 oznaczała ocenę bardzo niską, a 6 - ocenę bardzo wysoką. Respondenci wysoko ocenili atrakcyjność turystyczną gminy - 49\% z nich (79 osób) oceniło walory turystyczne gminy Susiec na 5, po 20\% ankietowanych (20 osób) na ocenę 4 i 6 . Pięć osób (3\%) postawiło najniższą ocenę - 1, a jedynie $8 \%$ pytanych (13 osób) oceniało atrakcyjność gminy Susiec na 3. Najwyżej atrakcyjność turystyczną gminy Susiec oceniło $20 \%$ respondentów (32 osoby), zaznaczając w kwestionariuszu ankietowym ocenę 6 .

Autorzy w kwestionariuszu ankietowym zapytali także o ocenę przedsiębiorczości mieszkańców gminy Susiec w zakresie turystyki (ryc. 5). Podobnie jak w pytaniu poprzednim, respondenci mieli do wyboru skalę ocen od 1 do 6 , gdzie 1 to ocena bardzo niska, 6 - ocena bardzo wysoka. Po 32\% spośród ankietowanych (52 osoby) postawiło ocenę 4 i 5 . Bardzo wysoką ocenę postawiło $21 \%$ respondentów (34 osoby), a tylko $2 \%$ ankietowanych (3 osoby) oceniło najniżej przedsiębiorczość mieszkańców gminy Susiec, zaznaczając w odpowiedziach ocenę 1.

Autorów badania interesowało również, jak ankietowani oceniają przedsiębiorczość władz samorządowych gminy Susiec. Rozkład odpowiedzi na to pytanie ilustruje rycinie 6. Tak jak w dwóch poprzednich pytaniach, respondenci mieli do wyboru skalę ocen od 1 do 6, gdzie 1 to ocena bardzo niska, 6 - ocena bardzo wysoka. Najwyższą ocenę władzom samorządowym w zakresie przedsiębiorczości dla gminy Susiec postawiło 23\% pytanych (52 osoby), podczas gdy 3\% ankietowanych (5 osób) nie podziela tego zdania i prace samorządowców oceniło na najniższą ocenę: 1 . Prace władz lokalnych bardzo dobrze oceniało 37\% respondentów (60 osób), a dobrze 29\% ankietowanych (47 osób).

Autorzy prezentowanego opracowania w kwestionariuszu ankietowym zadali respondentom pytania otwarte. Jedno z nich dotyczyło tego, co według ankietowanych jest największym rozczarowaniem na Roztoczu. Do najczęściej udzielanych odpowiedzi należały następujące kwestie: brak bazy gastronomicznej i noclegowej, złe drogi, mała liczba sklepów oraz zanieczyszczone miejsca turystyczne (pełne kosze na śmieci).

Drugie otwarte pytanie zadane respondentom w kwestionariuszu ankietowym brzmiało: „Co najbardziej urzeka Panią/Pana na Roztoczu?”. Wśród najczęściej udzielonych odpowiedzi na to pytania znalazły się następujące odpowiedzi: piękne lasy, cisza i spokój, zielone tereny, mało turystów, piękne widoki, czysty klimat, malownicze krajobrazy, przyroda, mili mieszkańcy gminy oraz dobre, nowe ścieżki rowerowe.

Inne otwarte pytanie brzmiało: „Co według Pani/Pana jest największym atutem rozwoju turystyki w gminie Susiec?”. Najczęściej udzielanymi odpowiedziami na to pytanie były: trasy spacerowe, kąpieliska, ścieżki rowerowe, walory przyrodnicze, szlaki turystyczne oraz czyste, nieskażone powietrze. Ostatnie pytanie otwarte miało na celu sprawdzić, co według ankietowanych należy uczynić, aby zwiększyć atrakcyjność turystyczną gminy Susiec. W tym pytaniu respondenci najczęściej udzielali następujących odpowiedzi: lepiej promować i reklamować region na terenie całego kraju, poprawić i rozbudować bazę gastronomiczną oraz noclegową, zorganizować wakacyjną sprzedaż produktów 
Ryc. 4. Rozkład odpowiedzi badanych na pytanie: „Jak ocenia Pan(i) atrakcyjność turystyczną gminy Susiec? (w skali 1 do 6, gdzie 1 to ocena bardzo niska, 6 - ocena bardzo wysoka)"

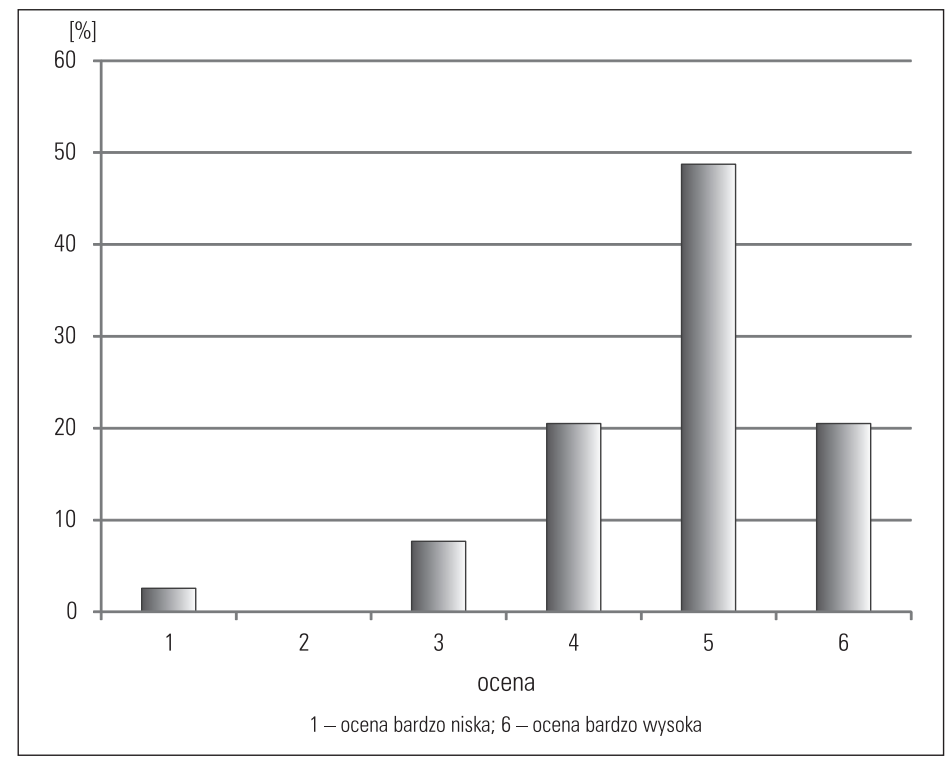

Źródło: opracowanie własne na podstawie przeprowadzonych badań

Ryc. 5. Rozkład odpowiedzi badanych na pytanie: „Jak ocenia Pan(i) przedsiębiorczość mieszkańców gminy Susiec w zakresie turystyki? (w skali 1 do 6, gdzie 1 to ocena bardzo niska, 6 - ocena bardzo wysoka)"

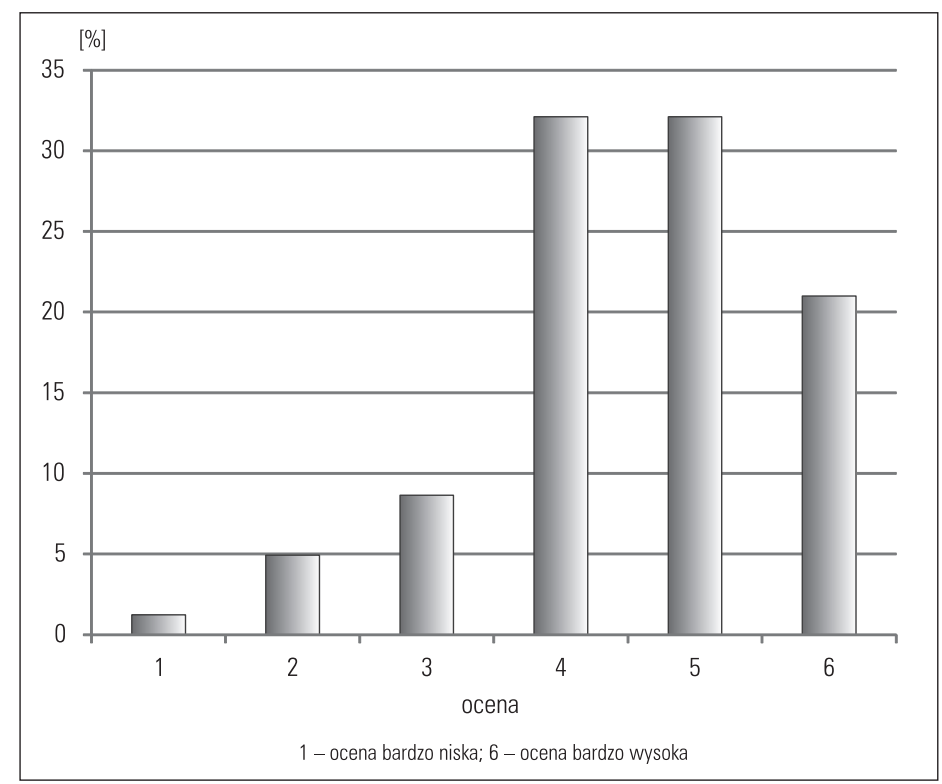

Źródło: opracowanie własne na podstawie przeprowadzonych badań 
Ryc. 6. Rozkład odpowiedzi badanych na pytanie: „Jak ocenia Pan(i) przedsiębiorczość władz samorządowych gminy Susiec w zakresie turystyki? (w skali 1 do 6, gdzie 1 to ocena bardzo niska, 6 - ocena bardzo wysoka)"

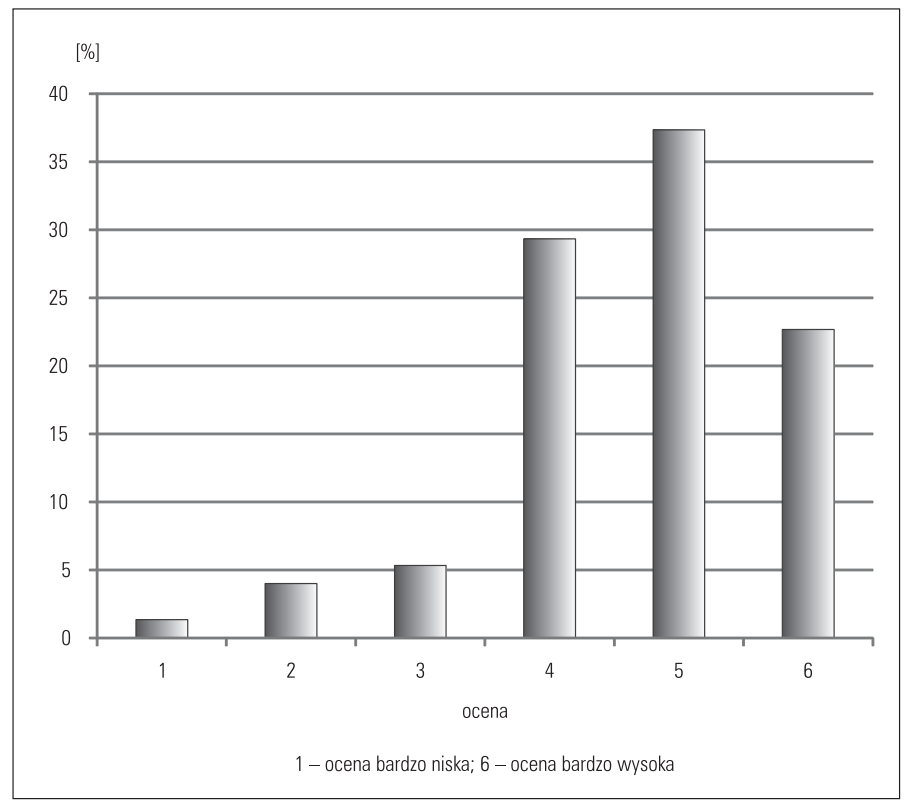

Źródło: opracowanie własne na podstawie przeprowadzonych badań

Ryc. 7. Model rozwoju turystyki w gminie Susiec

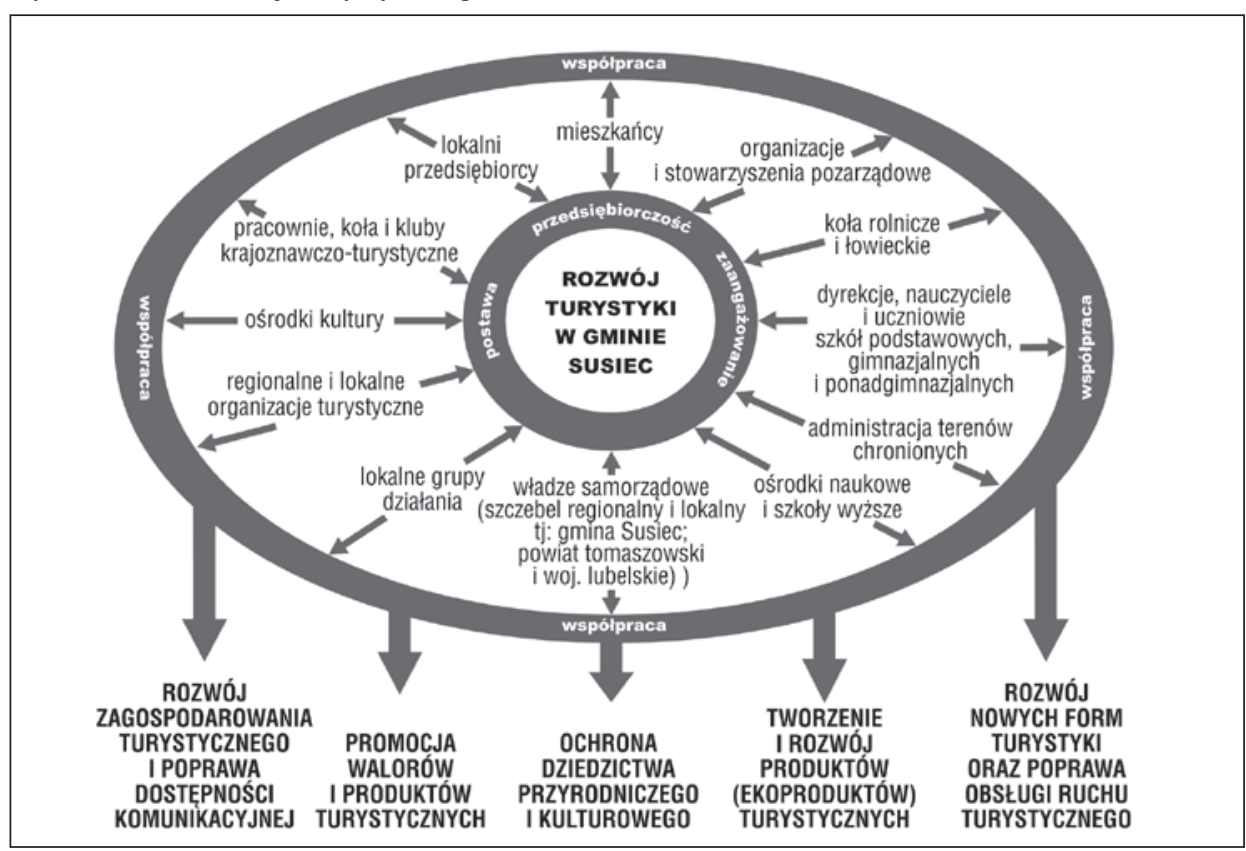

Źródło: opracowanie własne na podstawie przeprowadzonych badań 
regionalnych, zwiększyć liczbę atrakcji dla rodzin z małymi dziećmi, polepszyć komunikację publiczną w regionie, zbudować kąpieliska oraz zorganizować w sezonie atrakcje dla turystów, np. koncerty, festyny.

Autorzy tekstu na potrzeby artykułu skonstruowali model rozwoju turystyki w gminie Susiec (ryc. 7). Aby ten rozwój mógł przebiegać sprawnie i dobrze, potrzebna jest współpraca zarówno mieszkańców gminy, jak i władz samorządowych na szczeblu regionalnym oraz lokalnym. Potrzebne jest zaangażowanie lokalnych ośrodków kultury i krajoznawczych, ośrodków nauki i szkół wyższych oraz organizacji i stowarzyszeń pozarządowych. Mówiąc o rozwoju turystyki, ważna jest postawa lokalnych grup działania, dyrekcji i nauczycieli szkół a także regionalnych i lokalnych organizacji turystycznych, które swoim zaangażowaniem oraz wsparciem lokalnych przedsiębiorców i mieszkańców gminy zachęcą do działania i promocji gminy Susiec. Praca wszystkich poszczególnych grup oraz osób może się przyczynić do stworzenia i rozwoju markowego produktu turystycznego, a także rozwoju zagospodarowania turystycznego (np. przez tworzenie nowych miejsc noclegowych, punktów gastronomicznych). Ważna jest promocja walorów i produktów turystycznych powstających na opisywanym terenie oraz zapewnienie ich dostępności turystom odwiedzającym gminę Susiec.

\section{Zakończenie}

Przeprowadzone w ostatnim dziesięcioleciu w gminie Susiec inwestycje i inicjatywy ukierunkowane na podniesienie atrakcyjności turystycznej regionu skutkują stopniowo rosnącym ruchem turystycznym. W miesiącach wakacyjnych w 2016 r., przy najcenniejszych walorach turystycznych Roztocza Środkowego, odnotowano rekordową liczbę turystów. Wpływ na to miało szereg czynników, z których najczęściej wskazanymi przez respondentów były niestabilna sytuacja geopolityczna w Europie i obawy przed zamachami w krajach Europy Zachodniej i Południowej, otwarcie Wschodniego Szlaku Rowerowego Green Velo, a także wprowadzenie programu „500+”.

Władze samorządowe i przedsiębiorcy w gminie Susiec w dalszym planowaniu rozwoju turystyki powinni uwzględniać jeden z kluczowych parametrów, jakim jest „pojemność turystyczna” - tj. „granice odporności środowiska przyrodniczego, regionu recepcji i infrastruktury turystycznej na działalność turystyczną" (Zaręba, 2000: 15) W odniesieniu do gminy Susiec ważne jest, aby strategia rozwoju gminy była ukierunkowana na rozwój turystyki zrównoważonej (głównie ekoturystyki) i turystyki aktywnej, z precyzyjnym określeniem pojemności turystycznej: ekologicznej, kulturowo-społecznej i psychologicznej. (Zaręba, 2000). Ustalenie pojemności turystycznej gminy wymaga kompleksowej analizy specyfiki poszczególnych elementów środowiska geograficznego, specyfiki kulturowej regionu, walorów przyrodniczych, stanu zagospodarowania turystycznego, dostępności komunikacyjnej oraz motywów podróżowania turystów.

Setki turystów odwiedzających rezerwat „Nad Tanwią” w pogodne wakacyjne weekendy 2016 r. z jednej strony zapewne ucieszyły gospodarzy i mieszkańców gminy Susiec, z drugiej jednak strony dały poważny sygnał, że pojemność turystyczna rezerwatu osiąga graniczny poziom. Konieczne wydaje się więc w miejscach atrakcyjnych turystycznie stałe monitorowanie i kontrolowanie skutków ruchu turystycznego, zwłaszcza w okresach jego największego natężenia, tj. w trakcie długich weekendów oraz w miesiącach wakacyjnych. Odpowiednie i sprawne zarządzanie ruchem turystycznym przekłada się na zadowolenie 
klienta i nie powoduje przekroczenia psychologicznej i ekologicznej pojemności turystycznej. Jeśli jednak ta granica zostanie przekroczona, to turyści szukający na Roztoczu ciszy i niekażonej przyrody wyjadą mocno niezadowoleni i zapewne ponownie już tutaj nie powrócą ${ }^{3}$.

\section{Literatura \\ References}

Cabaj, W., Kruczek Z. (2007). Podstawy geografii turystycznej. Kraków: Wydawnictwo „Proksenia”.

Ewidencja ludności gminy Susiec na dzień 31.12.2016 r., Gmina Susiec.

Informator turystyczny. Roztocze 2011. (2011). Lokalna Grupa Działania „Roztocze Tomaszowskie”.

Magiczne Roztocze 2016. Magazyn turystyczny. Kalendarium. Informacje praktyczne. (2016). Zamość.

Mapa turystyczna: Susiec. Rowerem po Roztoczu. (2015). Rzeszów: Wydawnictwo Turystyczne Paweł Wład.

Ochrona środowiska ileśnictwo w województwie lubelskim w latach 2008-2012. (2013). Urząd Statystyczny w Lublinie, 126-127.

Oniszczuk-Jastrzębek, A. (2011). Otoczenie a przedsiębiorczość w warunkach globalizacji. Przedsiębiorczość - Edukacja, 7, 42-57.

Pawłowski, A. (2011). Roztocze Polskie i Ukraińskie. Przewodnik. Pruszków: Oficyna Wydawnicza Rewasz, 161-166.

Płaziak, M., Rachwał, T. (2015). „Przedsiębiorczy region” - zarys koncepcji w świetle analizy roli przedsiębiorczości w krajowej strategii rozwoju regionalnego. Przedsiębiorczość - Edukacja, 11, 37-49.

Podsumowanie pracy Rady Gminy Susiec (2010-2014). Pozyskano z: www.susiec.pl/images/docs/podsumowanie.pdf

Rowerowa koalicja na Roztoczu. Biuletyn Lokalnej Organizacji Turystycznej Roztocze, 183 (1).

Roztocze w oczach rowerzystów. Biuletyn Lokalnej Organizacji Turystycznej Roztocze, 186 (1).

Statystyczne vademecum samorząowca 2015. Gmina wiejska Susiec. (2016) Urząd Statystyczny w Lublinie. Pozyskano z: http://stat.gov.pl/vademecum/vademecum_lubelskie/portrety_gmin/powiat_tomaszowski/gmina_susiec.pdf

Susiec. Rowerem po Roztoczu. Informator turystyczny. Trasy rowerowe - noclegi - mapa gminy. (2016). Rzeszów: Wydawnictwo Turystyczne Paweł Wład.

Turystyka w województwie lubelskim w 2010 roku. (2011). Lublin: Urząd Statystyczny w Lublinie.

Warszyńska, J. (1971). Waloryzacja miejscowości z punktu widzenia atrakcyjności turystycznej (zarys metody). Prace Geograficzne, 27, 103-114.

Włodarczyk, B. (2009). Przemiany form aktywności turystycznej. Przykład krawędzi Wyżyny Łódzkiej. Szlakami Nauki, 29, 23.

www.muzeum.susiec.pl

www.roztoczewita.pl

www.susiec.pl/realizacje

www.susiec.com.pl/o-nas

www.turystyka.susiec.pl/news2.php?readmore $=167$

Zaręba, D. (2000). Ekoturystyka. Warszawa: Wydawnictwo Naukowe PWN.

Zioło, Z. (2016). Przedsiębiorczość w rozwoju układów lokalnych. Przedsiębiorczość - Edukacja, 16, 6-17.

Zioło, Z., Rachwał, T. (2012). Entrepreneurship in Geographical Research. In: P. Churski (ed.), Contemporary Issues in Polish Geography. Poznań: Bogucki Wydawnictwo Naukowe, 135-155.

\footnotetext{
${ }^{3}$ Autorzy składają serdeczne podziękowanie za udzielenie cennych informacji i pomoc w przygotowaniu niniejszego artykułu panu Zbigniewowi Naklickiemu - wójtowi Gminy Susiec - oraz panu Krzysztofowi Łagowskiemu - prezesowi Zarządu Roztoczańskiego Stowarzyszenia Agroturystycznego w Suścu.
} 
Franciszek Mróz, dr. Urodzony w 1975 r. w Przeworsku, geograf społeczno-ekonomiczny, pracownik naukowo-dydaktyczny (adiunkt) w Zakładzie Turystyki i Badań Regionalnych Instytutu Geografii Uniwersytetu Pedagogicznego w Krakowie. Wykładowca w Uniwersytecie Papieskim Jana Pawła II w Krakowie. Tytuł doktora nauk o Ziemi w zakresie geografii otrzymał w 2006 r. na podstawie rozprawy doktorskiej Geneza i typologia sanktuariów pańskich w Polsce, przygotowanej pod kierunkiem prof. dr. hab. Antoniego Jackowskiego w Instytucie Geografii i Gospodarki Przestrzennej UJ. W 1999 r. ukończył w Częstochowie Studium Podyplomowe „Pielgrzymki. Turystyka religijna”. Konsultant w Radzie ds. Migracji, Turystyki i Pielgrzymek Konferencji Episkopatu Polski. Członek Archicofradía Universal del Apóstol Santiago. Instruktor Krajoznawstwa Polski. W latach 2012-2014 prezes, a obecnie zastępca prezesa Bractwa św. Jakuba w Więcławicach Starych. Członek Zespołu Konsultacyjnego ds. Przygotowania Planu Działań na rzecz Rozwoju Turystyki Religijnej w Krakowie do roku 2020 powołanego przez Prezydenta Miasta Krakowa. Obecnie jego zainteresowania badawcze koncentrują się m.in. wokół zagadnień związanych z pielgrzymowaniem, turystyką religijną i turystyką kulturową w Polsce, genezą i funkcjonowaniem ośrodków pielgrzymkowych w Europie, a także europejskimi szlakami kulturowymi ze szczególnym uwzględnieniem Camino de Santiago - Drogi św. Jakuba. Jest autorem ponad 90 publikacji naukowych i ponad 50 publikacji popularno-naukowych z tego zakresu, a także redaktorem 12 prac zbiorowych. Od $2008 \mathrm{r}$. jest współorganizatorem corocznych międzynarodowych konferencji naukowych poświęconych problematyce historii i funkcjonowania Drogi św. Jakuba w Europie. Jest szczęśliwym mężem i ojcem trójki wspaniałych dzieci: Piotra (15 lat), Michała (13 lat) i Anny (8 lat). Interesuje się krajoznawstwem, fotografią i sportem.

Franciszek Mróz, PhD. Socio-economic geographer born in 1975 in Przeworsk, an academic (Assistant Professor) at the Department of Tourism and Regional Research of the Institute of Geography at the Pedagogical University of Cracow. Lecturer at the Pontifical University of John Paul II in Cracow. In 2006 he received the title of Doctor of Earth Sciences (PhD) in geography based on a doctoral dissertation entitled Origins and Typology of Sanctuaries in Poland, written under the supervision of Professor Antoni Jackowski, PhD, of the Institute of Geography and Spatial Management at the Jagiellonian University. In 1999 he completed post-graduate studies in Częstochowa in the field of "Pilgrimages. Religious Tourism." Consultant in the Migration, Tourism and Pilgrimage Council of the Polish Episcopal Conference. Member of Archicofradía Universal del Apóstol Santiago. Instructor of Polish cultural and regional studies. Chairman (during the period of 2012-2014) and currently Vice-Chairman of the Brotherhood of St. James in Więcławice Stare. Member of the Consultation Team for the preparation of the Action Plan for the development of religious tourism in Cracow until 2020, nominated by the Mayor of Cracow. His present research interests are concentrated on, for example, issues related to pilgrimages, religious and cultural tourism in Poland, origins and functioning of pilgrimage centres in Europe, and European cultural routes, especially Camino de Santiago - the Way of St. James. He is the author of more than 90 publications and more than 50 popular science publications from this field as well as an editor of 12 collaborative publications. Since 2008, he has been the co-organiser of annual international scientific conferences devoted to the history and functioning of the Way of St. James in Europe. $\mathrm{He}$ is also a happy husband and the father of three wonderful kids: Piotr (15), Michał (13) and Anna (8). He is interested in cultural and regional studies, photography and sports.

Kamila Ziółkowska-Weiss, dr. Absolwentka kulturoznawstwa z historią sztuki na Uniwersytecie Jagiellońskim oraz geografii na Uniwersytecie Pedagogicznym w Krakowie. Ukończyła podyplomowe studia na Uniwersytecie Ekonomicznym w Krakowie na kierunku zarządzanie turystyką międzynarodową. Adiunkt w Zakładzie Turystyki i Badań Regionalnych Uniwersytetu Pedagogicznego w Krakowie. Czynny pilot wycieczek. Autorka kilkunastu publikacji naukowych. Główne zainteresowania naukowe to turystyka kulturowa, mniejszości narodowe i grupy etniczne w Małopolsce oraz Polonia w USA. 
Kamila Ziółkowska-Weiss, PhD. Graduate of Culture studies at the Jagiellonian University and of Geography at the Pedagogical University of Cracow. She has graduated from postgraduate studies in international tourism management at the Cracow University of Economics. Since 2012 she has been a research worker, acting as an assistant in the department of Tourism and Regional Studies at the Pedagogical University of Cracow. An active tourist guide. The author of several academic publications. Her main academic interests are in cultural tourism, ethnic groups in Małopolska and Polish minority in the USA.

\section{Adres/Address:}

Uniwersytet Pedagogiczny im. Komisji Edukacji Narodowej w Krakowie Instytut Geografii

Zakład Turystyki i Badań Regionalnych

ul. Podchorążych 2

30-084 Kraków, Polska

e-mail: fmroz@wp.pl

e-mail:kamilacamela@wp.pl 